\title{
Cultural Looting and Restitution at the Dawn of the Cold War: The French Recovery Missions in Eastern Europe
}

\author{
Sophie Cœuré \\ Université Paris Diderot, France
}

\begin{abstract}
France was massively affected by Nazi looting and plundering, and was also probably one of the most successful countries in securing the return of cultural property. Drawing on recently opened Archives, this article reflects on the entangled history of the 'recovery' of works of art in Soviet occupation zones, in Poland, Czechoslovakia and in the GDR, focusing on the French investigations in the East. The micro history of this fieldwork allows for an interpretation of looting and restitution as a transnational moment of political and memory construction. The article first presents the organization of missions in the changing landscape of Europe, leading to the beginning of an East-West relationship on the ground. Then it analyses French and Soviet visions of the notion of looting, restitution and cultural property and finally concludes by attempting to interpret a loss of memory.
\end{abstract}

Keywords: Cold War, cultural heritage, France (Occupation and Liberation), Nazi looting and restitution, Soviet trophy policy, Rose Valland

France was massively affected by Nazi looting and plundering, but was also probably one of the most successful countries in securing the return of cultural property. Despite the liability of Vichy, the provisional government of General de Gaulle and subsequent governments of the $4^{\text {th }}$ Republic had managed to emerge as victors and to participate in the occupation of Germany and Austria. From 1945 they became involved in Allied search and recovery operations that mainly concerned their own country's cultural heritage. The French case was comparable to the Soviet case in this regard. The history of the French monuments men is quite well known now, and is embodied in the interesting person not of a man but of a woman: Rose Valland, who was both a key actor of the restitution policies, an accurate observer and a near maniac collector of reports, photographs and archives This history has been considered as part of the Occupation, the Resistance and the Liberation: Rose Valland herself placed her memoirs, Le front de l'art [The Art Front], in the context of the 1939-1945 war. ${ }^{1}$ More recently, Martine Poulain's work on libraries, that of Lynn Nicholas, Isabelle Le Masne de Chermont, Corinne Bouchoux on works of art as well as Patricia Kennedy Grimsted's and Sophie Coeuré's researches on archives, have considered the long history of restitution with regard to the construction of memory ${ }^{2}$.

\footnotetext{
${ }^{1}$ R. Valland, Le front de l'Art. Défense des collections françaises, 1939-1945 (3 ${ }^{\text {rd }}$ edn, Paris 2014). See L. Bertrand-Dorléac, L'art de la défaite, 1940-1944 (Paris 1993). M. Rayssac, L'exode des musées. Histoire des ouvres d'art sous l'Occupation (Paris 2007).

${ }^{2}$ M. Poulain, Livres pillés, bibliothèques surveillées: les bibliothèques publiques sous l'Occupation (Paris 2008). L. Nicholas, The rape of Europa. The fate of Europe's Treasures in the Third Reich and the Second World War (London-New-York 1994). I. Le Masne de Chermont, D. Schulman, Le pillage de l'art en France pendant l'Occupation et la situation des 2000 auvres confiées aux musées nationaux, contribution de la direction des musées de France et du centre Georges Pompidou aux travaux de la mission d'études sur la spoliation des Juifs de France (Paris 2000). C. Bouchoux, 'Si les tableaux pouvaient parler...' Le traitement politique et médiatique des retours d'œuvres d'art pillées et spoliées par les nazis, France, 1945-2008 (Rennes 2013). S. Coeuré, La mémoire spoliée. Les archives des Français, butin de guerre nazi puis soviétique de 1940 à nos jours $\left(2^{\text {nd }}\right.$ edn, Paris 2013). P. K. Grimsted, F. J. Hoogewoud, E. Ketelaar (ed.), Returned from Russia: Nazi Archival Plunder in Western Europe and Recent Restitution Issues ( $2^{\text {nd }}$ edn, Institute of Art and Law [UK], 2013). For a full bibliography of P. K. Grimsted's publications, see http://socialhistory.org/en/russia-archives-andrestitution/bibliography.
} 
These publications have not so far addressed the immediate post-war period and the beginning of the Cold War, however. Besides, the large body of literature devoted to the history of Nazi cultural looting and restitutions usually treats separately the Western and Soviet zones of military and administrative presence. The historiography has maintained the virtual absence of relations with the Soviet zone and Communist Europe, or has at best presented them as zones where French investigations were obstructed or precluded. The lack of archives on both sides of the Iron Curtain and the Soviet policy of secrecy that had concealed information about plunder and seizure ${ }^{3}$ combined with the results of a professional rift between East and West to create deep and enduring biases in the historiographical tradition. All cultural heritage professions were divided. The debate on the protection of cultural property unfolded at UNESCO without the USSR, which refused to join the 'pro-American' body, or Poland and Czechoslovakia, which withdrew in $1948^{4}$. Of course, the Détente allowed the socialist states to join heritage organizations like UNESCO and the International Council of Archives, leading to renewed debates about international rules of protection. But political and strategical interests hampered the implementation of legal agreements on the protection and restitution of cultural property. The issues discussed remained internal to each block: post-colonial archival litigation and restitution of War Archives to Federal Germany on one side, and more discrete restitutions of archives 'saved' by the Red Army to Socialist countries on the other side 5 .

Thus the entangled history of the 'recovery' of works of art in Soviet occupation zones, in Poland, Czechoslovakia and in the GDR has been largely neglected, be it the history of French missions and Soviet 'trophy brigades'explored since the 1990s, or the history of organizations responsible for these missions in Berlin, Prague and Warsaw ${ }^{6}$. Drawing on the archives of the French Services responsible for the recovery of cultural goods that were recently inventoried and opened by the French Ministry of Foreign Affairs, I would like to reflect here on the French investigations in the East and what they can teach us. The micro history of this fieldwork allows for an interpretation of looting and restitution as a transnational moment of political and memory construction. What was 'French cultural property' in this particular historical context? How did fait accompli, law and morality interrelate in the relationships among the various actors involved in the 'looting-inventoryrestitution' triad? How have the issues of looting, its nature and its causes been framed? How and according to what chronology was the incipient Cold War understood on the ground? Did this investigative work have long-term implications, and how was the memory of these 'East-West' missions and meetings preserved? In order to to develop answers to these questions, this article will first present the organization of missions in the changing landscape of Europe, leading to the beginning of an East-West relationship on the ground. Then it will analyse French and Soviet visions of the notion of looting, restitution and cultural property and finally conclude by attempting to interpret a dialectical relationship between secrecy, oblivion and memory.

Allied discussion of efforts to recover lost property began as early as 1942. The formal London Declaration of 5 January 1943 established common principles to condemn acts

\footnotetext{
${ }^{3}$ P. Knyshevsky, Dobycha. Tajny germanskyh reparacii (Moscow 1994).

${ }^{4}$ C. Maurel, Histoire de l'UNESCO, 1945-1975 (Paris, 2010). P. Singh, United Nations Educational Scientific and Cultural Organization (UNESCO): Creating Norms for a Complex World (London 2011).

${ }^{5}$ Coeuré, La mémoire spoliée. 178-180.

${ }^{6}$ See the pioneering works by K. Akinsha, G. Kozlov, Beautiful loot. The Soviet Plunder of Europe's Art Treasures (New York 1995) and K. Akinsha, 'Stalin's Decrees and Soviet Trophy Brigades: Compensation, Restitution in Kind, or “Trophies” of War?', International Journal of Cultural Property (2010, 17), 195 - 216.
} 
designated as 'open looting' and 'plunder' committed by Nazis in occupied Europe, but also included transactions apparently legal in form. Free France transposed it into law on 12 November 1943. An international policy had been outlined in the declaration of 1943, and then in the Inter-Allied Commission's work on protecting cultural property that was presided by the French historian Paul Vaucher in 1944-1945. ${ }^{7}$ But the USSR never served on the Vaucher commission, and no agreement was reached to establish a lasting interallied body for cultural restitution. Thus, while it was an inter-allied declaration, action fell to each government. The elaboration of an international legal framework was delayed and weakened. The search for, and restitution of looted property very quickly came to be managed at the Control Council level, especially in France's bilateral relations with its allies against Hitler, and then with the new Polish, Czechoslovakian, German and Austrian authorities. The context of a complex and changing diplomatic and institutional landscape left considerable scope for improvisation.

In 1945 came the time to organize taskforces and to send research 'missions' in a still violent and anomic Europe. The French experience with the first Kunstschutz 'protection services' that the Second Reich established to inspect and sometimes move archives, valuable books or artwork in the departments of the north during the First World War, did not help during the Occupation of 1940-44. ${ }^{8}$ By contrast, the political and institutional memory of the reparations required of Germany after 1918 was still strong. Thus, the Office des biens et intérêts privés (OBIP - Office for personal property and interests), founded in 1919 to execute the Versailles Treaty's economic clauses on personal property, was tasked with the identification and restitution of looted property under the joint authority of the Ministries of Foreign Affairs and of Finance. Meanwhile, the new Commission for the Recovery of Works of Art (Commission de récupération artistique, CRA) was tasked with investigating. Created by decree of the provisional government on 24 November 1944, the CRA was placed under the aegis of the Ministry of National Education, which entrusted its management to Albert Henraux, the president of the Conseil supérieur des musées (High council for museums). The Commission settled in the Jeu de Paume, thereby exorcising the memory of the ambiguities of French cultural collaboration ${ }^{9}$. It was in the Jeu de Paume that the Einsatzstab Reichsleiter Rosenberg (ERR - Reichsleiter Rosenberg Taskforce) and Goering's collaborators had accumulated looted paintings and then processed them for shipment to Germany. An interdepartmental committee was founded in February 1947 to strengthen relations between these various bodies in Paris.

France had two government and administrative headquarters in Germany. ${ }^{10}$ In Berlin the Groupe français du conseil de contrôle (GFCC - French Group Control Council) managed relationships with the three other occupying powers. In 1946, Rose Valland was

\footnotetext{
${ }^{7}$ Report of the American commission for the protection and salvage of artistic monuments in war areas, Washington, 1946 and minutes from the Vaucher commission, Archives diplomatiques de France, ministère des Affaires étrangères, La Courneuve, Fonds Récupération artistique (MAE, 209sup/297, MAE, 209sup 875), Paris.

${ }^{8}$ C. Kott, Préserver l'art de l'ennemi? Le patrimoine artistique en Belgique et en France occupées, 1914-1918, (Bruxelles, 2006). S. Coeuré, 'Le moment 1940 dans les archives publiques françaises: quel enjeu pour les contemporains?' in B. Fonck, A. Sablon du Corail (eds), 1940, l'empreinte de la défaite. Témoignages et archives (Rennes 2014), 27-41.

${ }^{9}$ S. Corcy, La vie culturelle sous l'Occupation (Paris 2005). E. C. Karlsgodt, Defending National Treasures: French Art and Heritage Under Vichy (Stanford UP 2011). J.-M. Dreyfus, Le catalogue Goering (Paris 2015).

${ }^{10}$ C. Lorentz, La France et les restitutions allemandes au lendemain de la seconde guerre mondiale, 1943-1954 (Paris 1998). P. Blumerel, La restitution des biens culturels pillés en France par les Nazis, une histoire sans fin, unpublished thesis, Sciences Po Lyon, 2005, available at http://doc.sciencespo1yon.fr/Ressources/Documents/Etudiants/Memoires/Cyberdocs/MFE2005/blumerel_p/pdf/blumerel_p.pdf (accessed 8 February 2015).
} 
named 'head of the fine arts section' of the GFCC's education and cultural affairs division, in direct contact with the Commission for the Recovery of Works of Art in Paris. Based in Baden-Baden, the military government of the French zone of occupation in Germany and Austria (FZO) was led by General Pierre Koenig. Cultural property represented only a small fraction of the issues managed by the FZO's Reparations and Restitution Branch. In the summer of 1947 this directorate employed 53 people, including Rose Valland as an 'administrator on secondment', and 15 experts. It managed temporary missions from France and Germany, as well as relations with the American, British and Soviet administrations and the French military representatives in these zones. In Austria, the French military administration directly dealt with the issue of restitution. In Poland and Czechoslovakia, diplomats managed restitution together with the OBIP.

This complex organizational structure, which was full of potential rivalry between the departments, only really worked for a few months, between the spring of 1946 and the beginning of 1948. Indeed, beginning in May 1945 the American and British monuments men of the Monuments, Fine Arts and Archives Program (MFA\&A) made some of their discoveries with the First French Army's Fine Arts service, which was led by painter Jean Rigaud. The service, which already included Rose Valland, the museum curator Pierre-Louis Duchartre and Jacques Dupont, inspector of historical monuments, accompanied the US Army as 'French representatives' in its discovery of repositories of works of art. Rose Valland, who had worked at the Jeu de Paume throughout the Occupation, had along with the museum director Jacques Jaujard played a key role in resisting the spoliation of art. ${ }^{11}$ Captain Rose Valland provided Captain James Rorimer with the list of art repositories she had secretly compiled on the basis of the ERR's information. She also knew, from 'spying' on Nazi services during the war, that some looted cultural property was evacuated and hidden in zones into which the Red Army was advancing. ${ }^{12}$ She very quickly reported that the Nikolsburg (Czech Mikulov) repository in Moravia was 'under the control of the Russian military'. ${ }^{13}$ It is only on 8 April 1946 that political and military relations among the occupation zones were legally formalized with the Allied Control Council's signing of a 'Quadripartite Procedure for Restitution', establishing processes for permanent missions. A quadripartite agreement to implement the restitution policy, however, was never signed. From June 1946, the Greater Berlin restitution office centralized information coming from France or gathered on the spot, and then shared it with the Reparations and Restitution Branch in Baden-Baden. The agreement enabled the establishment of permanent missions in Berlin as in the American and British zones, and in February 1947, of a 'permanent French reparations and restitution mission in the Soviet zone' that was led by an engineer, Georges Barillaud (or Barillot) ${ }^{14}$.

At this point, this joint initiative had already been weakened by US efforts to quickly settle the recovery of art for financial reasons - the management of collecting points was costly - and for political reasons, since the goal was to quickly transfer responsibilities to a democratic German government. The American and British governors, Lucius Clay and William Sholto Douglas, unilaterally decided to gradually cease restitution operations in

\footnotetext{
${ }^{11}$ C. Bouchoux, Rose Valland. La Résistance au musée (La Crêche 2006). F. Destremeau, Rose Valland, résistante pour l'Art (Grenoble 2008). R. Valland, Les carnets de Rose Valland. Le pillage des collections privées d'œuvres d'art en France durant la Seconde Guerre mondiale, E. Pollack, P. Dagen eds (Paris 2011).

${ }^{12}$ J. Rorimer, Survival: the salvage and protection of art in war (New York 1950).

${ }^{13}$ MAE,209 sup/327, report from R. Valland, J. Dupont, J. Rigaud, 16 May 1945. MAE, RA209 sup/894, a very comprehensive account by R. Valland: 'Artwork found in Nazi warehouses'. MAE, RA-209 sup/431, CRA report to General Cherrière, commander of French forces in Austria, 21 September 1945.

${ }^{14}$ P. Blumerel, p. 27. Akinsha, 'Stalin's Decrees and Soviet Trophy Brigades', p. 210.
} 
between April and June 1948. ${ }^{15}$ In September 1949 the CRA was closed, in 1950 the French representatives in the American Zone returned home, and then the OBIP was dissolved in 1953. The service for the return of works of art (Service de remise en place des œuvres d'art) that France created in 1949 in the FRG in order to bring all French existing services under the responsibility of Rose Valland operated until 1954. At this date the Paris protocol on the termination of the occupation regime, which was discussed at length in the new European integration plans, created a new restitution and reparations context within the framework of complete sovereignty of the German Federal authorities. While Eastern Europe entered the era of 'high Stalinism', the deterioration in relations between the USSR and its former allies also led to tensions ${ }^{16}$. In 1949 the bilateral agreement with Poland on the principle of reciprocal restitution of looted property located on each territory was suspended, while an agreement with Czechoslovakia was renewed in 1955 to maintain rights to restitution. ${ }^{17}$ In 1950 the Soviets transferred all of their rights to restitution to the German Democratic Republic, with which France did not maintain any diplomatic relations.

There is no synthetic work on missions in the American and British zones, where the vast majority of discoveries of looted cultural objects were made, and none on the work undertaken by the French with the Anglo-Saxon collecting points. ${ }^{18}$ Yet they are much better known than relations with the part of Europe in which the Red Army was present. What is more, French soldiers and experts - librarians, archivists, and museum curators who were often promoted to officer rank to facilitate their movement - provided a markedly different picture and chronology of the situation on the ground from that portrayed in the macro history of the Cold War and of cultural restitution.

While the American Art Looting Investigation Unit's report of May 1946 was right in stating that 'looting in the East remains unexplored', consistent information pointed to the existence of repositories that were already known (Nikolsburg) or discovered ${ }^{19}$. First came tip-offs: for example Masonic libraries and archives that Himmler gathered in Sława (German Schlesiersee) for his private library were flagged at the beginning of 1946 by an 'assistant librarian at the University of Poznan'. ${ }^{20}$ A French truck driver who was formerly a prisoner offered to retrieve furniture and paintings hidden at the Czechoslovakian border during the

\footnotetext{
${ }^{15}$ MAE 209 sup/312, 'Memorandum of the meeting held in Karlsruhe on 22 June 1948. Restitution of works of art'. 'Report on the end of art restitution in the American zone', Munich 22 March 1949.

${ }_{16}$ Among many works, see A. Applebaum, Iron Curtain: The Crushing of Eastern Europe, 1944-1956 (NY 2012); V. Mastny, Cold War and Soviet Insecurity (Oxford, 1996); V. Volokitina (ed) Sovetskyi faktor $v$ Vostochnoi Evrope 1944-1953, vol. 1, 1944-1948 (Moscow, 1999).

${ }^{17}$ Bouchoux, Si les tableaux..., 86-111. Bumerel, La restitution des biens culturels pillés, 55.

${ }^{18}$ This gap will be filled by Emily Löffler's Ph.D., Protection of cultural heritage and cultural policies in the French and American occupation zones (Kulturgüterschutz und Kulturpolitik in der französischen und amerikanischen Besatzungszone, University of Tübingen - Centre Marc Bloch, Berlin, in progress). For detailed investigations on Nazi repositories, see Grimsted, Hoogewoud, Ketelaar (ed.), Returned from Russia. On the ERR plunder and archives, see P. K. Grimsted, Reconstructing the Record of Nazi Cultural Plunder: A Guide to the Dispersed Archives of the Einsatzstab Reichsleiter Rosenberg (ERR) and the Postwar Retrieval of ERR Loot, http://errproject.org/survey.php (accessed February 10, 2016).

19 Art looting Investigation Unit Final Report. Confidential Washington DC. 1 May 1946, in MAE RA-209 sup/316.

${ }^{20}$ MAE, 209sup/240, Copy of a letter from the president of the Council of the Grand Orient de France (the oldest and largest masonic organization in France) to Georges Bidault, Minister of Foreign Affairs, 13 February 1946; Places where libraries plundered by the Germans were transferred or reported by the Germans, note from the CRA's book subcommittee, 7 January 1946.
} 
evacuation of Silesia. He proposed to search for 'all these treasures' himself, adding: 'I'll deal with the Russians and the Poles with a few litres of rubbing alcohol'! ${ }^{21}$ These were very quickly followed by interrogations of German soldiers or of their widows and daughters. Walter Borchers, an art expert who had worked on the Rosenberg task force in Paris, thereby revealed to Rose Valland 'the existence of a major repository of books that we did not know of until now in Poland (Russian zone) in Ratibor' (now Polish Racibórz, which was in fact not in the 'Russian zone', but under the control of the Red Army). ${ }^{22}$ These accounts were complemented by the work of leading experts in the American and British zones. Thus, in the spring of 1946 Rabbi Maurice Liber transmitted precise accurate information from the German Rabbi Leopold Neuhaus, who had just been liberated from the Theresienstadt camp (Terezín, in the Protectorate of Bohemia and Moravia) about the French Jewish collections sent, among other Judaica, to Terezin for 'cataloguing'. ${ }^{23}$ There were consistent reports about the Red Army's practices at the time. In October 1945 the Minister of Foreign Affairs alerted the French embassy in Moscow to the removal of books 'without any review', 'loaded in bulk into wagons headed to Russia' from Prague. At the beginning of 1946 the 'Russian relocation' of artwork that Hitler had accumulated in Dresden for the Linz museum was flagged. ${ }^{24}$ Seeking to obtain an overall view of the situation, Rose Valland and the French services strove to synthesize this scattered and sometimes false information by creating lists and maps, and then visiting in person to investigate. ${ }^{25}$

The first French incursion into the Russian zone in search of cultural objects was probably clandestine. In the spring of 1946 Rose Valland, who since the Occupation had been fixated on the extent of Goering's looting and forced buying - the Americans had only retrieved one part of the collection removed in 1945 - made her first trip to the Reichsmarschall's property in the Prussian Estate of Carinhall, located $60 \mathrm{~km}$ north of Berlin. Next, the signing of the allied agreement enabled the dispatch of several French missions in 1947. From 6 April to 20 May, Rose Valland conducted the 'first mission to enter the Soviet zone' in the company of Commandant Bernard Druène, an Army museum expert, Lysiane Tournier, a Russian interpreter, along with a chauffeur and Soviet officers. ${ }^{26}$ This tour led them to Halle, Schoenbeck, Freisburg, Weimar, Waidmannsheil, Jena, Dresden, Coswig, Leipzig, Rigenwald and Carinhall. From 26 April to 2 May 1947 restitution service attaché Georges Bois made a trip to Poznan (previously German Posen); M. Chevallier, the OBIP's representative in Warsaw, completed this mission in August of the same year. ${ }^{27}$ In a MayJune tour of Czechoslovakia, CRA expert Philippe Gangnat was able to visit Nikolsburg,

\footnotetext{
${ }^{21}$ MAE,209sup/312, Letter from François Dutin to the CRA, 30 August 1946, transmitted to Rose Valland by the reparations and restitution department of Baden Baden on 23 May 1951.

${ }^{22}$ MAE,209sup/875, questioning of Walter Borchers, no date.

${ }^{23}$ MAE,209sup/526, Liber Mission in the American zone, May 1946, handwritten 'Russian zone' note.

${ }^{24}$ MAE 209sup/375, copy of a letter from the Ministry of Foreign Affairs to the French Ambassador in Moscow, 24 October 1945. MAE,209sup/312, top secret telegram from the Berlin Command to the Reparations and Restitution Commission, 27 March 1946.

${ }^{25}$ See for example MAE,209sup/244, 'Artwork located in the Russian zone. Findings from interrogations conducted by Captain Rose Valland, CRA expert', 9 December 1946; MAE 209sup/375, 'Transfer points. Russian zone', January 1947; MAE, 209sup/164, 'Repository of books looted from France and currently in Poland', 8 March 1946; MAE n209sup/526 'Art objects looted in France and transported to Poland', no date (1947). Also see the syntheses in Archives nationales de France (AN), Pierrefitte-sur-Seine, Ministère de l'Education, archives de la sous-commission des livres de la CRA, AN F/17/17977-17982.

${ }^{26}$ MAE 209sup/707, 'Report from the French mission to recover art in the Russian zone' by Rose Valland, 23 May 1947 and report from Commander Druène, 16 June 1947.

${ }^{27}$ MAE 209sup/164, 'Report from G. Bois following his trip to Posen, Poland, 2 May 1947' MAE 209sup/240, Chevallier mission.
} 
several Bohemian castles and the Hohenfurth monastery (Czech Vyšší Brod) ${ }^{28}$ At the end of November-beginning of December, National Library curator Jean Prinet, who had conducted an extensive tour of the American and British repositories the previous year, travelled to Poland to Warsaw, Krakow, Poznan, Sława, Wrocław (Breslau) and Katowice (Kattowicz). ${ }^{29}$ In the same month of November 1947 Rose Valland, who had not managed to make her way to Jena to retrieve French libraries and military trophies, returned to Carinhall for a 'top secret' mission. By the end of the year, after several postponements, she was finally able to inspect the repository in Seissenegg, close to Amstetten in the Soviet zone of Austria. ${ }^{30}$ In January-February 1948 Jean Prinet's work in Poland was completed by Antoinette Poisson's visit to Racibórz (Ratibor) and Katowice. But Rose Valland, who had prepared a detailed itinerary in Silesia to search for archives and books looted by the ERR, was denied permission to visit Poland. ${ }^{31}$ In November Jean Pingaud, the OBIP's representative in Prague, inspected books stored at Prague University. ${ }^{32}$ The year 1949 marked Rose Valland's last visit to Carinhall in May, her incursion into Heidecksburg castle near Rudolstadt, where she located cannons, tapestries and paintings (she returned in July 1950, the meeting yielded the return of the treasures of the Army museum), and the Dresden investigation by Elie Doubinsky, French representative of the US MFA\&A, and then OBIP delegate after the MFA\&A ended. ${ }^{33}$

Until at least 1951 these missions were enhanced by frequent contacts with Berlin Karlhorst-based Soviet officers in charge of reparations and restitutions, as well as by the work of French diplomatic representations in Poland and in Czechoslovakia. The relationships were much less regular and intensive than those with the American and British zones, which were still providing a great deal of information on cultural property likely to be found in the East. The police also assisted by investigating suspicious transactions (since art experts were not allowed to investigate directly, but only to file claims on identified items). Finally, the requirement that Germans report any possibly looted item encouraged tip-offs. ${ }^{34}$ Reports from mobilized victims of spoliation were also received through the CRA and OBIP, but the public was not informed about the presence of cultural property in Red Army-controlled areas. As a result the only specific queries came from those who had reasonable grounds for believing that their archives or books might be of interest to Soviet authorities. This was the case of the former French communist party leader Boris Souvarine, who had become fiercely anti-Stalinist and was stripped by the Gestapo and ERR of political documents collected in the USSR and France. Souvarine spent his whole life looking for his 15,000 books and 8 cases of archives 'somewhere in Silesia', and then in Eastern Germany; all the while, a portion of them was secretly being held in Moscow's 'Special Archive'. ${ }^{35}$

\footnotetext{
${ }^{28}$ MAE 209sup/164, 'Philippe Gangnat - Mission in Czechoslovakia, May-June 1947'.

${ }^{29}$ AN, F 17980, Report from Jean Prinet, 15 May 1946; 'Mission in Poland to repatriate French books, November-December 1947', no date, MAE 209sup/164 Prinet mission.

${ }^{30}$ MAE 209sup/317, 'top secret' report from Rose Valland, 18 November 1947. MAE 209sup/375, letter from R. Valland to A. Henraux on the failure of the mission to Jena, 19 November 1947. MAE 209sup/489, file on 'Miss Valland's mission in the Soviet zone of Austria'.

${ }^{31}$ AN F/17/17980, 'Report from Miss Antoinette Poisson's study mission in Poland', 10 March 1948. MAE 209sup/164, correspondence between R. Valland and the president of the CRA, April 1948.

${ }^{32}$ MAE 209sup/378, letter from J. Pingaud to the director of the OBIP, 19 November 1948.

${ }^{33}$ MAE 209sup/312, 'Art recovery in the Russian zone. Visit to Karlshorst on 18 May 1949', signed R. Valland. 'Steps taken to recover the canons removed from the Army museum and the flags removed from France', 5 October 1950. MAE 209sup/256 Doubinsky mission and claims made to the Soviet authorities.

${ }^{34}$ Blumerel, La restitution des biens culturels pillés, 43.

${ }^{35}$ Coeuré, La mémoire spoliée, 77, 82, 185; Houghton Library, Harvard, Souvarine Archives, bMs Fr 375, 'Nazi pillage' file (1946-1978).
} 
It is fascinating to see how fieldwork with the Soviet, Polish, Czechoslovakian and East German authorities interweaved the imperatives of the incipient Cold War with often excellent interpersonal relationships. The personal involvement and tenacity of field experts were all the more important since their resources were limited and the restitution of artwork cultural valuables was rarely a priority over political or economic issues. As a woman, a discreet lesbian, a heavy smoker of American cigarettes, and a person without a degree but with great familiarity with the functioning of the French administration, Rose Valland knew how to use her image as a maverick to help save $\operatorname{artwork}^{36}$. In these times of uncertainty, she was left some latitude and we can understand through her reports and letters how she considered her patriotic duty, with great pragmatism, a firm wish to defend French interests, but without any feeling of revenge. However, her more 'personal' and 'unofficial' initiatives were not well received by her immediate superior at the Ministry of National Education, even if she was - as far as official documents let us know - not alone in trying to circumvent the unwieldy claims system by directly recovering cultural property in Allied occupation zones. Diplomats themselves made secret transactions: when France considered returning paintings that were purportedly from the Riga museum, 'provided that we obtain in exchange French works of art located in the Soviet zone', it also sought to 'avoid engaging on the very principle of restitution to Baltic countries, which were annexed by the USSR in $1940 .{ }^{37}$ Rose Valland, who had no apparent difficulty integrating into the virile atmosphere of occupation staffs, was a gifted storyteller of these long gatherings at which French and Soviet claims were discussed amid the sharing of cigarettes and cognac. Jean Prinet's impressions of Poland were very mixed: in 1946, he contrasted the 'friendliness of the Americans and the British' with the 'roughest of relations' with the Russians. In the autumn of 1947, after the complete victory of the 'democratic bloc', he underscored 'an atmosphere of cordiality strangely alternating with hostile distrust'. Philippe Gangnat described 'excellent relations' in Czechoslovakia but also noted the withholding of information about French books located in Prague.

France was not a participant in the 1945 Potsdam conference and was pressured by the 'Big Three' to abandon the principle of reparations in money or in kind, in addition to that of replacing lost artwork with German property of equivalent value, even if they were 'unique pieces of Art'. The country was alone in pushing for the systematic search for items to recover and the identification of each of the owners, public or private ${ }^{38}$. Hence, relations with the Americans and British were sometimes tense, with deep disagreement over the very principle of reparation and restitution. Nevertheless, the mutual trust that underpinned them never developed with the Communist authorities. Despite the personal connections, several missions were delayed or prevented, and there were interventions to conceal or remove French cultural property. It was the beginning of a grudging East-West relationship where each side tried to avoid being duped by the other, at all levels. Cultural politics could not be dissociated from general politics, or even from intelligence. Art restitution services used French counterintelligence notes from the DGER (Direction générale des études et recherches - General Directorate for Studies and Research), while Rose Valland compiled detailed files on the positions of the Red Army, the uranium mines in East Germany, and the sovietisation

\footnotetext{
${ }^{36}$ C. Bouchoux, 'Rose Valland' in D. Eribon (ed.), Dictionnaire des cultures gays et lesbiennes, Paris 2003, 485.

${ }^{37}$ MAE 209sup/312, ciphered telegram from Paris to the Reparations and Restitution Division, 13 March 1948.

${ }^{38}$ For a specific discussion of the Allied diplomatic and political impasse over restitution, see M. J. Kurtz, 'The Allied Struggle over Cultural Restitution, 1942-1947', International Journal of Cultural Property (2010-17), 177-194.
} 
of the Polish army, with hand-drawn maps. In the reports preserved, the Berlin blockade (April 1948-May 1949) emerges as a key turning point. It immediately complicated the work and led to the disengagement of the United States and of the USSR in favour of the two Germanys. On several occasions, however, Rose Valland reported the 'understanding' and 'kindness' of American officials at the Collecting Points, leading her to 'be optimistic about further restitution in the American zone'. In 1950, in final negotiations on the French accreditation of a new Soviet head of restitutions, she underscored that the Soviets made use of this demand within a wider geopolitical framework, and that they were de facto always giving orders to GDR authorities. Yet until at least 1951 this did not impede her from 'unofficially', and 'thanks to German collaboration', securing the return from eastern Germany of looted property (medals, paintings, ancient works, 'Hebraic manuscript and leather case from James de Rothschild's collection', etc.). ${ }^{39}$

Thus, individual decisions had to take account of Allied political issues, as well as the mental map of a rebuilding Central and Eastern Europe, on an almost daily basis. Diplomatic correspondence shows early concern with a situation that for a long time was more uncertain in Czechoslovakia than in Poland, and more generally, with the 'hardening of the Russian attitude' and 'its growing indifference to Western interests of any nature, be they economic, political or even cultural, in the countries subject to its influence'. ${ }^{40}$ In Germany and in Austria, France's policy of rebuilding and shaping the areas of education and culture interacted with artistic recovery, given that the need to call upon competent German collaborators quickly became apparent. ${ }^{41}$ But reconciliation with Germany progressed slowly, and ties with Stalinist USSR were far from being systematically cut.

The missions led by French experts were underpaid ( $\$ 90$ per month, the pay of a basic GI) and under-equipped ${ }^{42}$. They provided a very realistic picture of tremendous destruction exceeding that of Western Germany : the 'sorry sight' of Poland, roads strewn with military equipment, burned castles such as the ERR repository in Nikolsburg, starving people, Dantean images of Carinhall in ruins with its desecrated mausoleum, and the plunder by both German and Soviet troops, as occurred in the French consulate in Dantzig (Gdańsk in postwar Poland). In contrast to the swift organization of large repositories in the American, British and French zones, work in the East remained a haphazard search through 'piles' and 'jumbles'. This image of the field is one of the elements of a multifaceted reflection on the very notion of looting, retribution and restitution.

Reports from French officials incrementally developed an interpretation of the Soviet vision of reparations and restitution that prevented any real solidarity between the two most looted countries - France and the USSR. Daily field reports, combined with top-level discussions, help to explain how the the French dream to emerge at the forefront of all looted countries

\footnotetext{
${ }^{39}$ MAE 209sup/312, 'Restitution of artwork in the American zone. Mission from 15 June to 9 July 1949', Note of 5 October 1950 cited.

${ }^{40}$ Archives diplomatiques de France, ministère des Affaires étrangères (MAE), La Courneuve, Série Europe, sous-série Pologne, 199QO/83, 'French property and interests in Poland 1944-1949', unsigned note, 'Nationalisations in Poland', 3 October 1945 and passim, as well as MAE, Série Europe, sous-série Tchécoslovaquie, 207 QO68/64, Economic situation 1944-1946.

${ }^{41}$ C. Defrance, La politique culturelle de la France sur la rive gauche du Rhin, 1945-1955 (Strasbourg, 1994). E. Dussault, La dénazification de l'Autriche par la France. La politique culturelle de la France dans sa zone d'occupation, (Laval University 2005).

${ }^{42}$ Blumerel, , La restitution des biens culturels, 54.
} 
was crushed ${ }^{43}$. At the beginning of 1945 , an exchange between the CRA and the Soviet embassy in France was immediately fraught with misunderstanding. When Albert Henraux reported the looting of the Army Museum, the secretary of the embassy responded that the Germans 'had merely taken back their trophies'. 44 In May 1946, Rose Valland provided a clear analysis of the Soviet zone's peculiarity, despite the gestures of goodwill: no officers specialized in the fine arts; officials who had 'little concern for finding what had been plundered from them, probably preferring to compensate themselves with German goods', and who 'simply forwent their claims'; and tolerance for theft that rendered 'hopeless' any recovery of 'small plunder'. ${ }^{45}$ There were frequent reports of opportunistic plunder and resale involving Allied troops, and of trafficking by the Germans after 1949. But the image of Soviet soldiers eager for trophies that were legitimated if not legalized, and of a State that had begun removing a vast quantity of cultural property from Soviet-occupied territories while simultaneously engaging in to official inter-allied discussions, contrasted sharply with that of other nations ${ }^{46}$. After returning from Karlshorst in 1949, Rose Valland lamented the 'Soviets determination not to return anything'. She noted that the principle of mutual restitution at the heart of the 1946 agreement was actually fostering interest and facilitating the Soviet 'seizure' of French cultural property, from Gobelins tapestries to archives and statues on their way to being smelted. 'Unfortunately, we found that requesting a work of art only served to arouse their interest and consider it a good catch', she concluded. The Communists' 'very particular interpretation of property' also applied to the GDR, where art galleries, which were likely to still have paintings acquired under duress in occupied France, were declared 'property of the people'. ${ }^{47}$ Philippe Gangnat reported Czechoslovakia's reluctance to allow the French to conduct field inspections, lest they uncover the massive confiscation of property from citizens of German origin.

The CRA archives include many claims that received no response. The mutual restitution system nonetheless worked better than these pessimistic reports suggest. France traded many claims with its partners. Some of them were successful in one direction or the other, even if most of them remained unresolved. According to a review by Marie Hamon made in 1994, of 52,279 works or batches of works repatriated in 61 convoys, France had as of 5 June 1950 received more cultural property from the Soviet zone (742) than from the British zone (615), barely any less than repatriations from the French occupation zone $(1,553)$. The major Nazi repositories and hiding places were clearly in the American occupation zone (over $90 \%$ of returns) and in Austria (6,000 returns, including 450 cases from the major ERR repository in Amstetten in the Soviet zone, as most of the art seized by the ERR had already been transferred from Amstetten to Altausee in the US zone). For its part, France returned Russian paintings and archaeological materials from the Kherson museum in Crimea to the USSR. ${ }^{48}$

\footnotetext{
${ }^{43}$ Bouchoux, 'Si les tableaux... ', 86. Kurtz,' 'The Allied Struggle over Cultural Restitution'. Akinsha, 'Stalin's Decrees and Soviet Trophy Brigades'.

${ }^{44}$ MAE 209sup/397, DGER Bulletin, contacts between A. Henraux and the USSR embassy in Paris, 7 February 1945.

${ }^{45}$ MAE 209sup/312, draft of the report quoted in footnote 20. This whole highly critical passage was crossed out with a pencil.

${ }^{46}$ In the absence of scholarly works about western pillages, see K. Alford, Allied Looting in World War II: Thefts of Art, Manuscripts, Stamps and Jewelry in Europe (London, 2011). For the massive and systematic Soviet 'trophy' policy, see N. Naimark, chap. 2,3 ; C. Merridale, Ivan's War: Life and Death in the Red Army, 1939-1945 (New York, 2006) and B. Schechter, Government Issue: The Material Culture of the Red Army 19411945, PhD, University of California-Berkeley, 2015, unpublished.

${ }^{47}$ MAE 209sup/375, Rose Valland's account of her visit to Karlshorst, 28 May 1949, top secret.

${ }^{48}$ Lorentz, La France et les restitutions allemandes, from Marie Hamon, La récupération des auvres d'art spoliées (ministère des Affaires étrangères, unpublished 1994). Répertoire des biens spoliés en France durant la
} 
Mutual restitutions also worked with Czechoslovakia (808 batches received and several shipments), while shipments to Poland were never reciprocated, despite contacts with the missions and the Polish authorities. Polish restitution policy is not known enough to balance between different reasons - early sovietization of course, but also decisions taken by the Polish officers and civil servants. Precious items 'picked up' by the Polish authorities such as the library of the French institute in Warsaw and the major Slavic libraries looted in France and found on Polish territory were 'taken by the Russians'. 49 'It has been two years since Poland was freed from the German invader, and the Polish government has still not returned any cultural property looted by the Germans to France', a diplomat lamented in 1947. Indeed, Poland only returned a small part of the Polish Library seized by the Nazis from Paris ${ }^{50}$. By 1954, France had recovered 61,570 works of art, that is, $57,2 \%$ of total claims.

This review is based on official figures from the CRA and would need to be compared with convoy archives and the last returns from the Soviet zone. It does not account for all the millions of boxes of books and archives, or obviously for 'unofficial' returns that were directly handed to civilian or military authorities, if not downright illegal ones like the recovery of Carinhall's lions, which were French $16^{\text {th }}$ century statues that Goering placed at the entrance of his property and that Rose Valland later described spiriting away from the Soviets by hiding them in a moving van.

Only the opening of still-classified archives allowing an in-depth study of the Soviet Military Administration in Germany (SVAG), of the Committee of Defense (GKO) and of the 'Trophy Brigades' involving librarians and museum curators would enable insight into whether Rose Valland's analysis reflected a consistent Soviet attitude. Anyway, the claims' statement incites not to interpret as a fool's game the display of cordial relations with the Soviets through the beginning of the 1950s, as evidenced by the thank-you letters from Colonel Tiulpanov, director of the Propaganda Administration. Colonel Guliaiev, head of restitution in the Soviet zone wrote to Rose Valland in March, 1947: 'I hope that this is just the successful beginning of our working together for the mutual benefit of our two countries ${ }^{51}$ We know that there was real tension between a policy of quadripartite cooperation, intended in particular to secure the greatest economic compensation possible, and a more expeditious sovietisation on the ground. ${ }^{52}$ Besides, we also better know the Soviet Extraordinary Commission investigating 'Nazi-Fascist' Crimes (ChGK), and we can suggest the possibility that French and Soviet quests had many similarities, much more than

\footnotetext{
guerre 1939-1945, Commandement en chef français en Allemagne, Groupe français du conseil de contrôle, division des réparations et restitutions, bureau central des restitutions, 7 vol. (1947).

49 MAE RA209sup/164, 'Polish authorities' attitude regarding the restitution of French cultural property', undated.

${ }^{50}$ P. K. Grimsted, 'Twice plundered but still not home from the war: the fate of three Slavic libraries confiscated by the Nazis from Paris', Solanus (2002-16), 39-76.

${ }^{51}$ MAE 209sup/146, correspondences between Soviet officials and Rose Valland.

${ }^{52}$ N. Naimark, The Russians in Germany. A History of the Soviet Zone of Occupation 1945-1949 (Harvard, MA 1997). C. Defrance (ed), 'La zone d'occupation soviétique 1945-1949', special issue, Revue d'Allemagne et des Pays de langue allemande, 32 (2000). C. Möllet, A. Chubarian (ed), Politika SVAG v oblasti kultury, nauki $i$ obrazovanija: celi, metody, resultaty 1945 -1949 (Moscow, 2006). F. Slaveski, The Soviet Occupation of Germany: Hunger, Mass Violence and the Struggle for Peace, 1945-1947 (Cambridge, 2013).
} 
pessimistic French experts suggested when they saw the Soviets pursue a clear and large-scale accumulation of 'trophies', in a modus operandi that was anathema to that of the CRA ${ }^{53}$.

First, these two major occupied and looted countries had both broadly extended the notion of 'cultural property', even if it only became apparent a posteriori, by comparing CRA and Soviet Commission lists. Both France and the USSR were particularly interested in cannons and flags as national symbols. Rose Valland even proposed returning flags to Russia that had been taken by Napoleon and were located in Rudolstadt among French trophies. Besides, the postwar focus on art collections obscured the diversity of looted private cultural property claimed by France, mostly by the victims of the ERR-related Möbel-Aktion [furniture action], which had ransacked tens of thousands of appartments as their Jewish owners were deported or escaped. Thus the CRA sought to recover all works of art, books and archives it found regardless of their market value, but also went for furniture, carpets, 'household goods' etc., thereby to some extent sharing the Soviets' very extensive concept of 'recovery'. At the same time, the ChGK had been making detailed inventories in the Soviet liberated territories, showing how Soviet elites had entered at a large scale during the 1930s in an era of private consumption ${ }^{54}$. Since the USSR refused to provide lists of specific losses and preferred total removal, the French experts did not know of that work through Soviet claims, whereas Soviet experts had access to French lists. A shared perception of a 'cultivated' (kul'turny in Russian) universe ravaged by Nazi barbarians could nevertheless be a key to explaining some-good relationships between Soviet and French experts, even if France had finally been able to turn the page on the First World War and to abandon the idea that 'Germans must pay'.

France and USSR also partly shared the definition of a work of art, or an archive, by its cultural nature rather than by its legal state or private origin. No official or CRA expert challenged the basic principle behind the recovery of 'French' cultural goods. In the course of their searches they sometimes considered any books written in French or French paintings to be of 'French' origin and seized them at the risk of having to return the books in cases where they had been legally acquired by their German owners. What consisted of isolated slip-ups for the French was an operating principle for the trophy brigades, which systematically seized anything of 'Russian' heritage, even when it came from major figures or libraries of the antiSoviet emigration. ${ }^{55}$ These heritage reconstruction practices followed official guidelines but were never established as state policy by the USSR, nor identified as such by the French.

A third point of comparison would be the distinctly genocidal anti-Semitic dimension of Nazis' cultural plunder. Building on the notion of fascist crime, Soviet authorities considered the Soviet people as a whole to be victims, turning a blind eye to targeted antiSemitic persecution. ${ }^{56}$ While French Jewish property was apparently not an issue in the Soviet occupation zone, it remained conspicuously ignored with regard to restitutions by Czechoslovakia, which did not reply to any of the inquiries on the Terezin Judaica. Having sent Rabbis Maurice Liber and Gerson Epstein to the American zone, and Paul Klein, Hebrew

\footnotetext{
${ }^{53}$ N. Nikandrov, 'The transfer or the contents of German repositories into the custody of the USSR' in E. Simpson (ed), The spoils of war. World War II and Its Aftermath: The Loss, Reappearance and Recovery of Cultural Property (New York, 1997), 117-120. Konstantin Akinsha, Grigorii Koslov, 'The discovery of secret repositories', ibid, 162-165.

${ }^{54}$ N. Moine, 'La commission d'enquête soviétique sur les crimes de guerre nazis: entre reconquête du territoire, écriture du récit de la guerre et usages justiciers', Le Mouvement social (222-1, 2008), 81-109. N. Moine, 'La perte, le don, le butin. Civilisation stalinienne, aide étrangère et biens trophées dans l'Union soviétique des années 1940', Annales HSS (2013-2), 317-355.

55 Coeuré, La mémoire spoliée, 172-174.

${ }^{56}$ A. Salomoni, L'Unione Sovietica e la Shoah. Genocidio, resistenza, rimozione (Bologna 2007).
} 
specialist at the National Library, to the Offenbach repository, France considered Jewish cultural property to be 'French' first, causing tensions with the 'Jewish commissions' that had come from the United States in order to file claims for heirless property ${ }^{57}$. The State of Israel's request to recover 'works of art that had belonged to missing Jews' baffled both Albert Henraux, who noted the 'unfortunate confusion between a matter of religion and a matter of nationality', and Rose Valland, who opposed the missions of all countries working for their 'national heritage' and the Jewish organizations 'working at the international level'. 'Pressure' from American Jews gave rise to heated discussion at the OBIP. ${ }^{58}$

Neither the difficulty of assigning a 'national' origin to many of the objects involved, nor the different concepts of categories and value were discussed openly during the inter-allied encounters. Beyond the mission reports it was not going to draw general conclusions about Soviet practices from these observations, all the more so as the Iron Curtain divided Europe and ended concrete relantions and intellectual exchanges between experts and lawyers.

[line break]

The work thus begun by meticulous field surveys, allowing for the contrast as well as comparison of East-West definitions of looted cultural goods, seizure and plunder (often described in detail in the interrogations of Germans), and the idea of reparation and restitution therefore remained unfinished. A combination of factors explains how this documentation and reflection were forgotten, beginning with the construction in France of a selective memory of the Occupation, its actors and its victims. For at least twenty years after 1945, the 'collective memory' of the war and the Holocaust remained mainly locked away in national boundaries $^{59}$. France's gradual forgetting of cultural property looting is now well known. ${ }^{60}$ It is easy to understand why Rose Valland's report in 1950 of repositories of furniture 'that had belonged to French Jews' in the Soviet zone, in Poland and in Czechoslovakia did not go anywhere, since the Möbel-Aktion was not covered by any French reparation policy after the closing of the CRA and until the establishment of the Commission for the compensation of victims of spoliations resulting from the anti-Semitic legislation in force during the Occupation (Commission pour l'indemnisation des victimes de spoliations, CIVS) in $1999^{61}$. The expunging of Nazi plunder, the transfer of remaining collections to German and Austrian authorities, and the cover-up of misappropriations of looted property all resulted from the complex linkages between the unspoken collaboration and anti-Semitic persecution in France and the wish to rebuild the country and Europe anew. Ordinary victims - Jewish people, leftist activists, Freemasons, 'white' Russians, etc. were soon left alone with their private grief. Major art collectors like the Rotschild family were more eager to put the issue on the agenda, but the French War Damages Act excluded 'sumptuary goods' like artwork and

\footnotetext{
${ }^{57}$ G.J. Rickman, Conquest and Redemption: A History of Jewish Assets from the Holocaust (New Brunswick London 2007).

${ }^{58}$ MAE 209sup/373, letter from A. Henraux to J. Jaujard, 23 June 1949; letter from R. Valland to E. Bizard, head of the central bureau of restitution in Berlin, 16 June 1950. Bouchoux, Si les tableaux..., 101.

${ }^{59}$ D. Levy, N. Sznaider, The Holocaust and Memory in the Global Age (Temple UP 2006). H. Rousso, Vichy, l'événement, la mémoire, l'histoire (Paris 2001). F. Azouvi, Le mythe du grand silence. Auschwitz, les Français, la mémoire (Paris 2012).

${ }^{60}$ A.Liskenne, 'Autour des restitutions de biens culturels de 1944 à nos jours', in A. Sumpf, V. Laniol (ed), Saisies, spoliations et restitutions, Archives et bibliothèques au XXe siècle (Rennes 2012), 313-326.

${ }^{61}$ L. Auslander, 'Coming home? Jews in Postwar Paris', Journal of Contemporary history (40-2, 2005), 237259. S. Gensburger, J.-M. Dreyfus, Nazi Labor Camps in Paris (Oxford-NY 2011).
} 
manuscripts, dampening hopes of compensation. Cultural property that was neither discovered nor restored were left uncovered by French public policies.

The battle of the CRA experts had led to the espousal of political and moral values combining the need to make French heritage 'whole' with anti-Nazism free of any resentment toward the German people. This allowed Rose Valland to form lasting friendships with certain German curators and librarians. However, she persisted in updating lists of gallery owners, artists, experts and movers involved in the sale of artwork to the Germans. But in France, the interests of art dealers and buyers under the Occupation, and the interests of the French administration, which faced a scandal in 1950 over the theft of repatriated paintings, converged to make cultural looting a taboo subject. ${ }^{62}$ In 1965 the Beaux-Arts director Jean Châtelain wrote to Rose Valland to urge her to 'let go of the past', arguing that the first consideration should be 'those who are alive now and all those who will follow them' and who dream not of 'oblivion', but rather of 'peace and fraternity'. 63

The rift between the West and Communist Europe was the second main reason for the loss of this first thread of reflection on the management of looting in the East. The actors on the ground experienced it as they were striving to work with the Communist authorities. In spite of human affinities, unscripted encounters, and shared mistrust of Britsh and American policies, the mission reports clearly show how, in less than five years, French experts cut contacts with their Russian, Polish or Czech counterparts. Jean Prinet and the French representatives in Poland sent alerts on the risk their informers faced and called for an 'energetic attitude' paired with an 'attentive and discreet friendship with those who still believe in the projection of French culture'. Rose Valland reported on the presence of the Soviet political police and heard about the dispatch 'to Siberia' of the head of the restitution mission in the French zone for being too conciliatory towards the French ${ }^{64}$. The intelligence briefs she received and probably helped draft were harsh about 'the Stalinist method of military conquest, which is infinitely more flexible and clever than Hitler's method' ${ }^{65}$

In fact, the updating of lists of displaced cultural property in the Soviet zone of Germany (then DDR), Poland and Czechoslovakia quickly became useless. When they are available, Soviet archives clearly show that the governments and experts were aware of the illegality of their trophy policy under international law, especially when the trophies came from Nazi plunder in Europe. Soviet policy of keeping trophies secret gradually developed under the direct supervision of Stalin until the end of the $1940 \mathrm{~s}^{66}$. It meant that the presence of French cultural property in the East was merely suspected. The suspicion was compounded by the USSR's publicized restitutions to its Polish and East German allies in the 1950s. 'In the course of our research, however, we rued not always having the ease of access and work in the Soviet occupation zone of Eastern Germany that we enjoyed in the Western zones' Rose Valland concluded in her 1955 synthesis on Restitution of art in Eastern Europe. ${ }^{67}$ None of the French experts was a specialist on Central and Eastern Europe: they returned to their daily

\footnotetext{
${ }^{62}$ Bouchoux, Si les tableaux..., 80. See in particular MAE 209sup/707, File on the Acquisition of Artwork by Germans.

${ }^{63}$ MAE 209sup/412, letter from J. Châtelain to R. Valland, $1^{\text {st }}$ April 1965.

${ }^{64}$ MAE 209sup/312, note of 12 October 1950. The fate of SVAG officers after there return in URSS is very badly known.

${ }^{65}$ AN, F/17/17980, report by Prinet, op. cit. MAE 209sup/546, Note of 24 December 1947 by Jean de Beausse, the French chargé d'affaires in Poland. MAE 209sup/317, Report by R. Valland, 13 October 1948. MAE 209sup/312, Note of 5 October 1950 cited. MAE 209sup/310, file on the 'Soviet Zone. November-December 1949', unsigned note.

${ }^{66}$ Knyshevsky, Dobycha. Tajny germanskyh reparacii.

${ }^{67}$ MAE 209sup/146, report by R. Valland, 'Art Restitution in Eastern countries', 3 November 1955.
} 
work in museums, archives, libraries, and their quest fell into oblivion in the absence of public international policies. Against the backdrop of the world's division into two camps, Rose Valland stayed rather on her own in her interest in the Eastern Europe she had experienced in the aftermath of the war. Pretending to believe that the Soviet seizure of French works resulted from 'confusion' over their origin, she stated her hope that talks would resume during destalinization: 'As one of the nations that like France was most looted by the Nazis, the USSR will understand the importance that we attach to recovering this valuable part of our national heritage, especially if we appeal to its goodwill and interest in matters of Art' ${ }^{68}$ Valland never had opportunities to investigate beyond the Iron Curtain. She died in 1980, ten years before the reopening of a transnational debate about looted war cultural properties.

The ties and relationships between European countries across the continent remained substantial until the end of the 1940s. The story of this restitution process can clearly contribute to the reshaping of the immediate post-war reconstruction's history ${ }^{69}$. Field encounters between French experts and representatives of the USSR and of states under Soviet influence had revealed deep tensions over the notions of legitimate compensation, restitution, 'trophies' and unfulfilled obligations. Collaboration based on good personal relations, shared anti-Nazism, and an informal level of agreement on the definition of cultural property, had nonetheless allowed for significant restitution. Allied work laid legal foundations and resulted in consideration of looted cultural property at the Nuremberg trials, but the conditions for an international political or legal debate on cultural restitution $v s$ trophies of war were not present and no joint reflection unfolded ${ }^{70}$. These difficult, later interrupted encounters between East and West cultural heritage experts encourages further explorations of war memories and oblivion. The Cold War and changing European societies gradually solidified a memory framework that explains both the public silences and the failure to sustain the network of experts involved at the time. Contacts endured only at a personal level, and remained internal to the western block. Rose Valland's bitterness is understandable in light of the interrupted treasure hunt, the suppressed past, and a geopolitical pragmatism ignoring once-shared moral principles about the need to restitute. However, the knowledge accumulated on the ground about comparative cultural looting was not lost. Rose Valland saw to the repatriation of French service archives. ${ }^{71}$ The documentary treasures that the French experts accumulated on both Nazi looting and the dispersal of cultural property in the aftermath of the war remains their legacy to a history that had seemingly stalled in the 1950s and started anew with the fall of the Berlin Wall and the opening of archives.

\section{Acknowledgments}

\footnotetext{
${ }^{68}$ Ibid.

69 M. Mazower, 'Reconstruction: The Historiographical Issues', in Post-war Reconstruction in Europe: International Perspectives, 1945-1949, Past and Present (2011), Supplement 6, p.20

${ }^{70}$ W. Sandholtz, "Plunder, Restitution and International Law', International Journal of Cultural Property (2010), 147-176.

71 See the introduction to the latest series of CRA inventories and related records: http://www.diplomatie.gouv.fr/fr/archives-diplomatiques/s-orienter-dans-les-fonds-et-collections/fonds-etcollections-d-archives/article/fonds-d-archives-lies-aux-suites\#sommaire_1 (accessed 15 February 2016).
} 
Translated into English by Carolyn Avery. This article was presented at the 'Looted Art and Restitution in the Twentieth Century' conference that took place in Cambridge from 18 to 20 September 2014. I would like to thank the wonderful 'troika' that organized this conference: Bianca Gaudenzi, Astrid Swenson and Mary-Ann Middelkoop, and all the participants in my panel discussion. I would also like to express my deep gratitude to Anne Liskenne, the heritage curator at the Archives Department of the French Ministry of Foreign and European Affairs, for her generous and friendly help.

\section{Biographical Note}

Sophie Coeuré is Professeure des Universite's (Full Professor) at the University Paris Diderot Paris 7, Director of the MA in History and Comparative civilizations, Assistant director of the Research Center 'Laboratoire Identités, cultures, territoires'. Her research interests include Russian and European modern diplomatic, cultural and intellectual history, Communism in a globalized world, cultural diplomacy, Western reception of Soviet experience, displaced Cultural Properties during and after the Second World War, comparative political and cultural History of Archives. Her most recent books include: La mémoire spoliée. Les archives des Français, butin de guerre nazi puis soviétique (de 1940 a nos jours) (Paris 2007), which won the Prix Henri Hertz de la Chancellerie des Universités de Paris, and Pierre Pascal. La Russie entre christianisme et communisme (Lausanne 2014). Together with J. Catteau and J. Bouvard, she edited Pierre Pascal, Journal de Russie (19281929) (Lausanne 2014). 